\title{
Microalgae and probiotic bacteria as biofloc inducers in a hyper-intensive Pacific white shrimp (Penaeus vannamei) culture
}

\author{
Francisco J. Jiménez-Ordaz ${ }^{1}$, Marco A. Cadena-Roa ${ }^{1}$, Juan M. Pacheco-Vega ${ }^{2}$ \\ Maurilia Rojas-Contreras ${ }^{1}$, Dariel Tovar-Ramírez ${ }^{3}$ \& Pablo M. Arce-Amezquita ${ }^{1}$ \\ ${ }^{1}$ Universidad Autónoma de Baja California Sur (UABCS), Unidad Pichilingue \\ La Paz, Baja California Sur, México \\ ${ }^{2}$ Universidad Autónoma de Nayarit (UAN), Escuela Nacional de Ingeniería Pesquera (ENIP) \\ San Blas, Nayarit, México \\ ${ }^{3}$ Centro de Investigaciones Biológicas del Noroeste (CIBNOR), Laboratorio de Fisiología Comparada \\ y Genómica Funcional, La Paz, Baja California Sur, México \\ Corresponding author: Juan M. Pacheco-Vega (pachecovjm@yahoo.com.mx)
}

\begin{abstract}
Biofloc systems in Pacific white shrimp (Penaeus vannamei) culture generate floccules that remove wastes, and hence, biofloc formation is promoted for shrimp production. This study evaluated the induction of biofloc formation using microalgae and probiotic bacteria in hyper-intensive Pacific white shrimp culture. The experiment was performed for six weeks in tanks $\left(28,000 \mathrm{~L}\right.$ each) stocked $350 \mathrm{ind} \mathrm{m}^{-3}$ and weight of $1400 \pm 30 \mathrm{mg}$. Three treatments were assessed: 1) with two diatoms: Grammatophora sp. and Navicula sp., 2) with Navicula sp., and 3) without diatoms. All treatments were added with Schizochytrium sp. and Lactobacillus fermentum TD19. The following parameters were monitored during culture: ammonium, nitrites, nitrates, environmental variables, floccules volume, microorganism presence, the bromatological composition of biofloc, and growth performance parameters of $P$. vannamei. Our results indicated that the three induced biofloc presented a similar volume $\left(8.34 \pm 4.8 \mathrm{~mL} \mathrm{~L}^{-1}\right)$ and ammonium concentration $\left(<1.0 \mathrm{mg} \mathrm{L}^{-1}\right)$. Treatment 1 generated floccules with the highest concentration of ciliates, rotifers, nematodes, lactic acid bacteria, and the lowest concentration of Vibrio spp. $\left(1.2 \times 10^{3} \mathrm{UFC} \mathrm{mL}^{-1}\right)$, evidencing a significant difference in bromatological composition, with the highest protein and lipid values $(28.12 \pm 0.50$ and $22.44 \pm 0.80 \%$ biofloc dry weight, respectively) and the best feed conversion ratio (0.89). Based on these results, we suggest that Schizochytrium sp., L. fermentum, and two diatoms should be used to induce biofloc in a hyper-intensive culture of $P$. vannmaei in order to provide a supplementary nutritional intake, which can constitute an advantage to reduce commercial feed rations.
\end{abstract}

Keywords: Penaeus vannamei; biofloc inducers; Lactobacillus fermentum; Schizochytrium sp.; Grammatophora sp.; Navicula sp.

\section{INTRODUCTION}

Biofloc technology is used in Pacific white shrimp (Penaeus vannamei) culture to improve production (Avnimelech 2012, Crab et al. 2012), given that it favors the formation of flocs comprised of microorganisms with nutritional value for shrimp (Timmons et al. 2002). The formation of floccules in cultures is relevant since these aggregates act as indicators of the system conditions; thus, aquaculture promotes the production of floccules with nutritional quality.
The induction of floccules in shrimp culture has been assessed employing different carbon sources such as molasses, cane sugar, dextrose, and rice bran, mainly to reduce the concentration of total ammoniacal nitrogen in order to bring solutions to high-density cultures (Serra et al. 2015). Molasses is the most widely used carbon source to produce biofloc in shrimp culture (Schveitzer et al. 2013, Correia et al. 2014, AriasMoscoso et al. 2018), given that the biofloc generated with this carbon source represent a nutritional input, which reduces feed costs (Hari et al. 2004). Despite the

Corresponding editor: Mauricio Laterça 
floccules induce a difference in water quality, nutritional value, and other aspects such as morphology and microbial community composition, the carbon sources selected should favor the growth of specific bacteria, protozoans, and phytoplankton (Crab et al. 2012).

Moreover, Wei et al. (2016) suggested that bioflocs should contain microalgae, given that these microorganisms produce essential molecules for aquaculture (Roy \& Pal 2015). Different microalgae such as diatoms and cyanobacteria grow in flocs, constituting an important source of feed for bacteria, ciliates, rotifers, and nematodes due to their nutrients content (Hargreaves 2013). Grammatophora sp. and Navicula sp. are diatoms employed to feed marine organisms (Ferreira et al. 2014), and Schizochytrium sp. plays an essential role against diseases and in maintaining the health of cultures due to its capacity to produce docosahexaenoic acid (DHA; 22:6n-3) (Sun et al. 2014), which justifies its potential biotechnological use in aquaculture.

Microalgae also help maintain adequate concentrations of nitrogen-derived compounds in the water column (Quijano et al. 2017). These microorganisms remove nitrates and avoid this residual accumulation, which affects shrimp growth (Xu \& Pan 2013). Thus, microalgae benefit the water quality and prevent pathogenic bacteria such as Vibrio, which can cause shrimp death (Lv et al. 2017). On the other hand, probiotics in microalgae culture can reduce the abundance of pathogenic bacteria, such as Vibrio spp. (Ma et al. 2009, Balcázar 2017); furthermore, favor the loss of nitrogen compounds. The research performed by Lin et al. (2004) and Xie et al. (2019) evidenced that the use of probiotics enhances shrimp growth by improving nutrient absorption, which benefits culture biomass.

One of the essential requirements to establish microalgae and probiotics culture is that these microorganisms should be easy to handle. In this study, the addition of Lactobacillus fermentum (T19), Schizochytrium sp., Grammatophora sp. and Navicula sp., which present good growth performance shrimp at ambient temperature and outdoor cultures was evaluated. Pacheco-Vega et al. (2018) employed Schizochytrium sp. in Pacific white shrimp culture and obtained favorable results. Therefore, in our study, the addition of Grammatophora sp. and Navicula sp. into biofloc technology was assessed as an enhancer of the formation of biofloc; parameters such as the concentration of nitrogen compounds, bromatological composition of biofloc, and abundance of Vibrio spp. were evaluated during culture. Microalgal growth was also determined during the experimental period and the concentration of microorganisms and composition (lipids and proteins) of induced bioflocs. The effects of these parameters over $P$. vannamei growth in a hyperintensive culture were evaluated to reduce the commercial feed intake and foster reductions in shrimp aquaculture costs.

\section{MATERIALS AND METHODS}

\section{Biological material and experimental design}

The study was performed at Unidad Pichilingue from Universidad Autónoma de Baja California Sur (UABCS), Mexico, during September and October 2016. Strains of Schizochytrium sp., LPU-1 and the diatoms Grammatophora sp., LPU-6 and Navicula sp., LPU-7 were obtained at the strain repository of Unidad Pichilingue. Microalgae were cultured in cylindrical tanks (400 L) with F/2 medium (Guillard 1975) (plus silicates for diatoms) at ambient temperature $\left(24-33^{\circ} \mathrm{C}\right)$ for $48 \mathrm{~h}$. Lactobacillus fermentum TD19 probiotic bacterium (international key: TD19), isolated from the digestive tract of Penaeus vannamei, was provided by Laboratorio de Ciencia y Tecnología de Alimentos (UABCS). This probiotic bacterium was cultured in cylindrical tanks (400 L) using F/2 medium (Guillard 1975), molasses $\left(2.5 \mathrm{~g} \mathrm{~L}^{-1}\right)$, and sodium citrate $(1.17 \mathrm{~g}$ $\left.\mathrm{L}^{-1}\right)$. Microalgae were added to geomembrane tanks $\left(28,000 \mathrm{~L}\right.$ capacity) at a concentration of $2 \times 10^{4}$ cells $\mathrm{mL}^{-1}$. Inoculation was performed according to each of the three treatments to evaluate biofloc. Treatment 1 consisted by Grammatophora sp. and Navicula sp. plus Schizochytrium sp. and T19 (BFD1), treatment 2 by Navicula sp. plus Schizochytrium sp. and T19 (BFD2), and treatment 3 contained Schizochytrium sp. and T19 (BFS). Schizochytrium sp. was selected for all treatments due to its benefits from its symbiotic interaction with Lactobacillus fermentum- T19 (Hernández-Castro $\&$ Pacheco-Vega 2015, Pacheco-Vega et al. 2018). The bacterium T19 was added to each tank at an initial concentration of $3.5 \times 10^{3}$ colony forming units (CFU) $\mathrm{mL}^{-1}$. F/2 medium (Guillard 1975) was supplied as the nutrient source at a concentration of $\mathrm{F} / 14$, and molasses was used as a carbon source $\left(15 \mathrm{~g} \mathrm{~m}^{-3}\right)$. Microalgae and bacteria were harvested and inoculated every $8^{\text {th }}$ day to maintain constant densities in the biofloc technology (BFT) cultures. Aeration was supplied with a blower at a rate of $100 \mathrm{hp} \mathrm{ha}^{-1}$ coupled to fiberglass aerators (three per tank) type airlift pump conditioned with outlet openings with micropore tube in the lower part. Tanks seawater was sand-filtered, further filtered with $10 \mu \mathrm{m}$ and $1 \mu \mathrm{m}$ filters; the water exchange (5\%) was performed every two days.

\section{Shrimp culture}

Pacific white shrimp postlarvae were bought from commercial laboratory "Acuacultura Mahr S.A. de C.V. de Baja California Sur, Mexico". Postlarvae were 
acclimatized and maintained under these conditions before the test; when reached a mean weight of $1400 \pm$ $30 \mathrm{mg}$ in eight weeks of culture, the juvenile shrimp were deposited in nine (three tanks per treatment) outdoor geomembrane tanks $(28,000 \mathrm{~L}$ each) to a density of 350 ind $\mathrm{m}^{-3}$. Two hundred liters of microalgae and $20 \mathrm{~L}$ of the bacterium TD19 were added to each tank (for each treatment) every eight days. Shrimp were fed $35 \%$ protein commercial feed (Nutrimentos Acuícolas Azteca, Guadalajara, Jalisco, México) every three hours. According to shrimp biomass, the initial feeding rate $(6 \%)$ was decreased to $4.4 \%$, estimated from biometric data. These data were also employed to estimate the quantity of molasses added daily according to the carbon-nitrogen (C:N) relationship, which was $15: 1$, as suggested by Avnimelech (1999).

\section{Water quality}

Temperature and dissolved oxygen were measured every three hours using a digital oximeter (YSI EcoSense DO200A), $\mathrm{pH}$ was recorded once a day with a potentiometer (Hanna, Hi 98127), salinity with a manual refractometer (BTX-1, VEE GEE), and the biofloc volume (BFV) was determined weekly using Imhoff cones (1 L during $30 \mathrm{~min}$ ) (Avnimelech 2009). Total ammonium, nitrites, and nitrates were determined following the protocols suggested in the manufacturer's instructions (YSI ${ }^{\circledR}$, Photometer Ecosense $9500^{\circledR}$ ). The alkalinity and $\mathrm{pH}$ levels were maintained above $100 \mathrm{mg}$ $\mathrm{L}^{-1}$ and 7.5, respectively, and adjusted whit sodium bicarbonate $\left(\mathrm{Na}_{2} \mathrm{CO}_{3}\right)$. Fifty milliliters of water were sampled from each tank in triplicate every eight days to perform these analyses.

\section{Microorganisms within biofloc}

Assessment of lactic acid bacteria and the genus Vibrio

During the experimental period, three samples were obtained from each tank every eight days to determine LAB and Vibrio spp's concentration in bioflocs and the guts of three shrimps per tank. Bacteria were cultured using the extension per plate technique (APHA 1995) as follows: $0.1 \mathrm{~mL}$ of homogenized samples were inoculated with the respective dilutions in De Man, Rogosa and Sharpe (MRS) agar (DIFCO, USA) for lactic acid bacteria, and thiosulfate-citrate-bile-sucrose (TCBS) agar (DIFCO, USA) for Vibrio spp., incubation was performed at $30 \pm 2^{\circ} \mathrm{C}$ during $24 \pm 2.0 \mathrm{~h}$. After this period, colonies were counted to determine the colony concentration forming units $\left(\mathrm{CFU} \mathrm{mL} \mathrm{m}^{-1}\right)$.

\section{Assessment of induced microalgae and microor- ganisms associated with biofloc}

Three samples of water containing biofloc were collected from each tank every eight days to quantify the microalgae concentration employed to induce biofloc. Dilutions were performed with water; microalgae were counted in a Neubauer chamber using an optical microscope Olimpus ${ }^{\circledR}$. A sample of $1 \mathrm{~mL}$ of water containing biofloc was collected. Lugol's solution was used as a fixative to determine the number of microorganisms (ciliates, rotifers, and nematodes) associated with biofloc. Microorganisms were observed and counted in a Sedgewick-Rafter chamber. Identification was performed with specialized literature (Alandro-Lubel 2009).

\section{Proximate analysis of biofloc}

The composition of biofloc was determined as follows: $1 \mathrm{~L}$ of water containing biofloc was sampled from each tank at days 15, 30, 45, and 60. Samples were centrifuged (10000 rpm) in an E.C. Centra GP8R and rinsed with distilled water to remove excess salts, and frozen at $-80^{\circ} \mathrm{C}$. After this step, samples were lyophilized in a Telstar ${ }^{\circledR}$ Cryodos freeze dryer and maintained at $23^{\circ} \mathrm{C}$ until processing in triplicate. Ash content was determined by incineration (Terlab Muffle), at $550^{\circ} \mathrm{C}$ for $24 \mathrm{~h}$. Ash weight was measured using an analytical balance (Vibra HT-224 R). Protein content was obtained according to the procedures suggested by Lowry et al. (1951), modified by Malara \& Charra (1972) for 4-6 mg samples. Carbohydrate content was determined using the protocols indicated by Dubois et al. (1956) and White (1987) for 4-6 mg samples. Lipids were extracted following the methods stated by Bligh \& Dyer (1959); the determination was performed using the gravimetric method for $20-30 \mathrm{mg}$ samples.

\section{Performance parameters of shrimp}

One hundred shrimp per tank were randomly selected each week; weight was measured using a Gram FC laboratory balance to the nearest 0.001 to $0.1 \mathrm{~g}$. The survival rate $(\%)$, weekly weight gain $\left(\mathrm{g} \mathrm{week}^{-1}\right)$, relative growth rate $(\%)$, and feed conversion rate (FCR) was calculated as follows: average weight $(\mathrm{g})=$ total biomass / final number of individuals; weekly weight gain $\left(\mathrm{g}_{\text {week }}{ }^{-1}\right)=$ gain weight $/$ week of cultivation; biomass $(\mathrm{g})=$ final average wet weight $\times$ final number of individuals; feed conversion rate $(\mathrm{FCR})=$ feed consumption / final biomass; survival rate $(\%)=$ (final number of shrimps / initial number of individuals) $\times 100$. 


\section{Statistical analyses}

Data were verified with the assumptions of homocedasticity and normality (Bartlett's and KolmogorovSmirnov tests). One-way ANOVA (Zar 1996) was employed to evaluate water quality parameters, microorganism concentration (bacteria, induced microalgae, ciliates, rotifers, and nematodes), BFT composition, survival (arcsine transformed), final weight, specific growth rate, and feed conversion ratio (FCR). The Tukey's test was approached in cases where significant differences were detected $(P<0.05)$ using Statistica 8.5.1 for Windows.

\section{RESULTS}

\section{Water quality}

During the experiment, values of water quality, temperature, dissolved oxygen, salinity, and $\mathrm{pH}$ were similar among the three treatments with no significant differences $(P<0.05)$. Dissolved oxygen ranged 5.5$6.3 \mathrm{mg} \mathrm{L}^{-1}$, temperature $25-31^{\circ} \mathrm{C}$, salinity $36-38 \mathrm{~g} \mathrm{~L}^{-1}$, alkalinity $116.66-120.83 \mathrm{mg} \mathrm{L}^{-1}$, and $\mathrm{pH}$ 7.3-8.0 (Table 1). Nitrogen compounds maintained similar mean concentrations among the three treatments. No significant differences $(P>0.05)$ were found among treatments regarding biofloc volume. The initial values (day 7) of flocs concentration were the following: 4.10 $\mathrm{mL} \mathrm{L}{ }^{-1}$ in BFDI, $3.80 \mathrm{~mL} \mathrm{~L}^{-1}$ in BFD2, and $3.45 \mathrm{~mL} \mathrm{~L}^{-1}$ biofloc inoculated with Schizochytrium sp. (BFS). In turn, the final values (day 42) were the following: 13.45 $\mathrm{mL} \mathrm{L}^{-1}$ in BFD1, $13.27 \mathrm{~mL} \mathrm{~L}^{-1}$ in BFD2, and $13.11 \mathrm{~mL}$ $\mathrm{L}^{-1}$ in BFS.

The maximum levels of ammonium were recorded during the first week of the experimental period in all treatments: BFS with $2.0 \mathrm{mg} \mathrm{L}^{-1}$, BFD1 with $1.96 \mathrm{mg}$ $\mathrm{L}^{-1}$, and BFD2 $1.83 \mathrm{mg} \mathrm{L}^{-1}$. These values decreased in the three treatments since week two. Ammonium levels during week three were as follows: $0.92 \mathrm{mg} \mathrm{L}^{-1}$ in BFD1, $0.54 \mathrm{mg} \mathrm{L}^{-1}$ in BFD2, and $0.79 \mathrm{mg} \mathrm{L}^{-1}$ in BFS. Values lower than $1.0 \mathrm{mg} \mathrm{L}^{-1}$ were maintained until week four. In BFS, the level of ammonium increased (1.21 $\left.\mathrm{mg} \mathrm{L}^{-1}\right)$ in week five, while the treatments with diatoms presented values lower than $0.95 \mathrm{mg} \mathrm{L}^{-1}$ until the end of the experiment (Fig. 1a).

During the first two weeks of culture, nitrites were maintained in concentrations lower than $0.4 \mathrm{mg} \mathrm{L}^{-1}$ at all treatments. In week three, BFS presented values higher than $0.9 \mathrm{mg} \mathrm{L}^{-1}$, and by week four, nitrite concentration in the three treatments ranged from 1.11 to $1.63 \mathrm{mg} \mathrm{L}^{-1}$. The highest concentrations of nitrites were detected during week six: in BFD1 $3.53 \mathrm{mg} \mathrm{L}^{-1}$, in BFD2 $3.15 \mathrm{mg} \mathrm{L}^{-1}$, and in BFS $3.58 \mathrm{mg} \mathrm{L}^{-1}$ (Fig. 1b).
In the first week, nitrate concentrations were lower than $1.50 \mathrm{mg} \mathrm{L}^{-1}$ at all treatments, and values increased towards the culture's end. During week three, all treatments reached values ranging from 7.42 to 17.22 $\mathrm{mg} \mathrm{L}^{-1}$, and BFS increased up to $47.27 \mathrm{mg} \mathrm{L}^{-1}$ in week five. The maximum nitrate concentrations (51.00-59.50 $\mathrm{mg} \mathrm{L}^{-1}$ ) at all treatments were detected during the last week of the experimental period (Fig. 1c).

\section{Microorganisms in biofloc}

\section{Lactic acid bacteria (LAB) and genus Vibrio}

Lactic acid bacteria and Vibrio spp. were quantified each week in terms of CFU per $\mathrm{mL}^{-1}$ of water with biofloc and from the gut of cultured shrimp. At the initial time, $\mathrm{LAB}$ in water ranged $3.68-5.31 \times 10^{3} \mathrm{CFU}$ $\mathrm{mL}^{-1}$ and increased gradually until the last days of the culture period, reaching the following values: 22.32, 5.51, and $4.16 \times 10^{3} \mathrm{CFU} \mathrm{mL} \mathrm{m}^{-1}$ in BFD1, BFD2, BFS, respectively (Fig. 2a). In turn, the highest concentrations of Vibrio spp. in water were detected during week two as follows: $4.37,3.05$, and $5.14 \times 10^{3} \mathrm{CFU}$ $\mathrm{mL}^{-1}$ in treatments BFD1, BFD2, and BFS, respectively. The concentration of Vibrio spp. decreased from week three to week six, with the following final values: $1.50,1.83$, and $4.10 \times 10^{2} \mathrm{CFU} \mathrm{mL} \mathrm{mL}^{-1}$ in treatments BFD1, BFD2, and BFS, respectively (Fig. 2a).

The concentrations of LAB in the digestive tract of shrimp increased gradually during the experimental period. At the initial time, values were: $3.08,5.79$, and

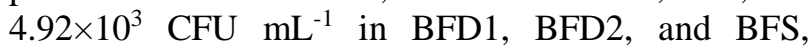
respectively; and by week six, values were: $16.77,1.65$ and $1.75 \times 10^{5} \mathrm{CFU} \mathrm{mL} \mathrm{m}^{-1}$ in BFD1, BFD2 and BFS, respectively (Fig. 2b). Vibrio spp. in the digestive tract of cultured shrimp increased in week two with the following concentrations: BFD1 with $4.37 \times 10^{3} \mathrm{CFU}$ $\mathrm{mL}^{-1}, \mathrm{BF} 2$ with $5.42 \times 10^{3} \mathrm{CFU} \mathrm{mL}^{-1}$, and BFS with $6.75 \times 10^{3} \mathrm{CFU} \mathrm{mL}^{-1}$. By week six, Vibrio spp. counts decreased, in BFD1 values were $1.00 \times 10^{3} \mathrm{CFU} \mathrm{mL}^{-1}$, in BFD2, $1.55 \times 10^{3} \mathrm{CFU} \mathrm{mL}^{-1}$, and in BFS, $4.86 \times 10^{3}$ CFU mL $\mathrm{mL}^{-1}$ (Fig. 2b).

\section{Inoculated microalgae and other microorganisms associated with biofloc}

Inoculated microalgae remained in the culture treatments throughout the whole experimental period. In particular, Schizochytrium sp. presented concentrations of $4.9 \times 10^{5}$ cells $\mathrm{mL}^{-1}$ since week four at all treatments. Although this week, its concentration decreased at all treatments (Fig. 3); however, no significant differences were detected $(P<0.05)$ within each treatment.

Values of Navicula sp. and Grammatophora sp. increased during the first four weeks; in treatments BFD1 
Table 1. Water quality values in biofloc induced with Schizochytrium sp., Grammatophora sp. and Navicula sp. (BFD1), biofloc induced with Schizochytrium sp. and Navicula sp. (BFD2), and biofloc induced with Schizochytrium sp. (BFS), in Penaeus vannamei culture during six weeks. Mean values \pm standard deviation. The absence of superscript letters indicates no significant differences among treatments (One-way ANOVA, $P<0.05$ ).

\begin{tabular}{lrcr}
\hline \multirow{2}{*}{ Parameter } & \multicolumn{3}{c}{ Treatment } \\
\cline { 2 - 4 } & \multicolumn{1}{c}{ BFD1 } & \multicolumn{1}{c}{ BFD2 } & \multicolumn{1}{c}{ BFS } \\
\hline Oxygen $\left(\mathrm{mg} \mathrm{L}^{-1}\right)$ & $5.98 \pm 0.33$ & $5.92 \pm 0.30$ & $5.92 \pm 0.34$ \\
Temperature $\left({ }^{\circ} \mathrm{C}\right)$ & $7.12 \pm 1.98$ & $27.22 \pm 1.91$ & $27.18 \pm 1.94$ \\
pH & $7.72 \pm 0.29$ & $7.71 \pm 0.31$ & $7.69 \pm 0.34$ \\
Salinity $\left(\mathrm{g} \mathrm{L}^{-1}\right)$ & $37.62 \pm 0.70$ & $37.72 \pm 0.74$ & $37.72 \pm 0.69$ \\
Alkalinity $\left(\mathrm{g} \mathrm{L}^{-1}\right)$ & $120.83 \pm 17.67$ & $120.83 \pm 17.67$ & $116.66 \pm 19.17$ \\
Biofloc volume $\left(\mathrm{mL} \mathrm{L}^{-1}\right)$ & $8.34 \pm 4.70$ & $8.29 \pm 4.80$ & $8.30 \pm 4.82$ \\
\hline
\end{tabular}
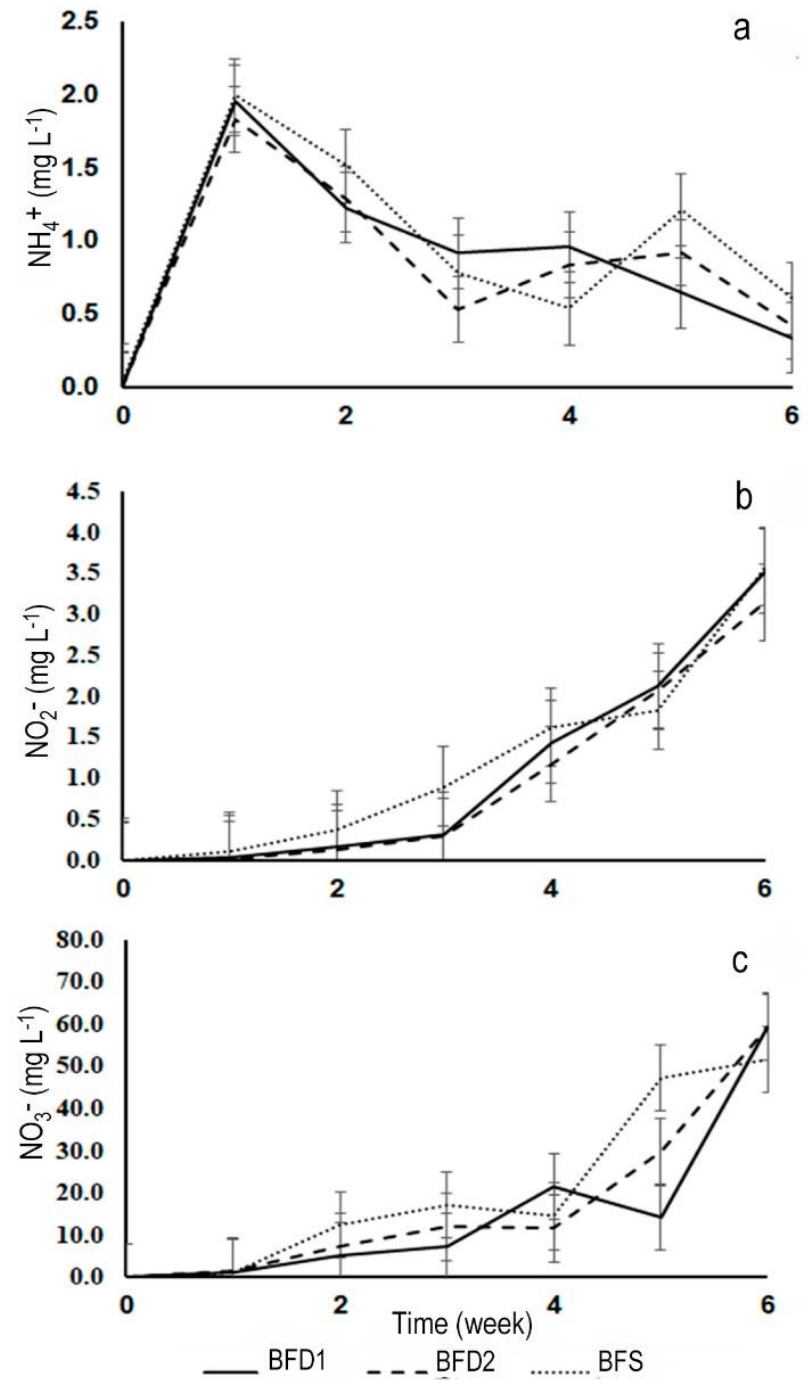

Figure 1. Concentrations of a) ammonium, b) nitrites, and c) nitrates in biofloc induced with Schizochytrium sp., Grammatophora sp. and Navicula sp. (BFD1), biofloc induced with Schizochytrium sp. and Navicula sp. (BFD2), and biofloc induced with Schizochytrium sp. (BFS) for Penaeus vannamei culture during six weeks. Values are presented as means \pm standard deviation. and BFD2, Navicula sp. presented concentrations of $8.60 \times 10^{5}$ and $5.90 \times 10^{5}$ cells $\mathrm{mL}^{-1}$, respec-tively (Figs. 3a-b). The concentration of Grammatophora sp. in BFD1 showed little variation during culture; $1.20 \times 10^{5}$ cells $\mathrm{mL}^{-1}$ were counted in week five (Fig. 3a).

Other microorganisms associated with biofloc during culture were ciliates, rotifers, and nematodes; the latter presented similar values among the three treatments. Contrastingly, during the first two weeks, ciliates showed significant differences $(P<0.05)$ in treatment BFS concerning BFD1 and BFD2, which contained diatoms. Since week two, the presence of ciliates was detected with mean values of 14,9 and 3 ind $\mathrm{mL}^{-1}$ in BFD1, BFD2, and BFS, respectively. These microorganisms reached values up to 40 ind $\mathrm{mL}^{-1}$ in the three treatments during the experimental period. Rotifers were found since week three. Maximum values were detected during week four in BFD1 with 53 ind $\mathrm{mL}^{-1}$, in BFD2 with 44 ind $\mathrm{mL}^{-1}$, and week six in BFS with 33 ind $\mathrm{mL}^{-1}$. Nematodes were detected since week three at all treatments with maximum concentrations of 32, 29, and 33 ind $\mathrm{mL}^{-1}$ in BFD1, BFD2, and BFS, respectively (Figs. 3a-c).

\section{Bromatological analysis}

The two treatments that contained diatoms showed a higher content of protein, lipids, and carbohydrates. The biofloc proximal composition varied among treatments. In particular, the protein percentage was significantly higher in treatments BFD1 and BFD2. The highest lipid percentage $(P<0.05)$ was obtained in treatment BFD1, and the highest carbohydrate percentage $(P<0.05)$ was detected in BFS (Table 2$)$.

\section{Growth performance of shrimp}

The growth performance parameters of $P$. vannamei exposed to different induced bioflocs showed that initial weight, final weight, and weekly and daily growth 

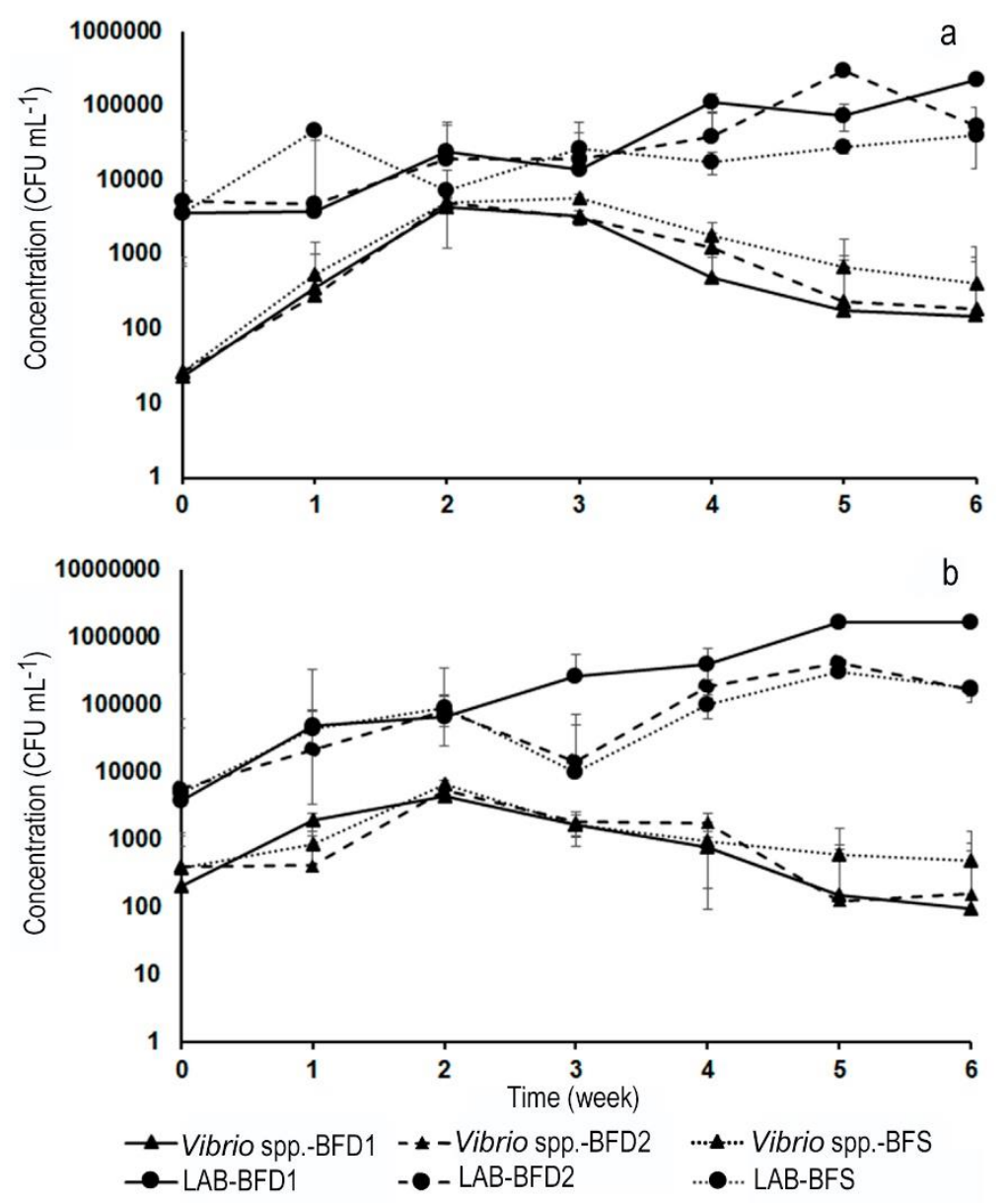

Figure 2. The concentration of lactic acid bacteria (LAB) and Vibrio spp. in a) water with biofloc and b) in shrimp gut during six weeks of Penaeus vannamei culture in biofloc induced with Schizochytrium sp., Grammatophora sp. and Navicula sp. (BFD1), biofloc induced with Schizochytrium sp. and Navicula sp. (BFD2), and biofloc induced with Schizochytrium sp. (BFS). Mean values \pm standard deviation.

rate were similar $(P>0.05)$ among the three treatments evaluated. However, shrimp survival and growth were higher $(P<0.05)$ in the treatment-induced with Schizochytrium sp., Grammatophora sp. and Navicula sp. (BFD1) (Table 3).

\section{DISCUSSION}

The physical and chemical variables of water in the three treatments whit induced bioflocs were maintained within favorable values to culture the Pacific white shrimp Penaeus vannamei. Due to the shrimp density and the volume evaluated, it was relevant to control dissolved oxygen (DO) concentration to avoid considerably, which would affect shrimp survival. Krummenauer et al. (2011) experimented with shrimp at densities similar to our study, and these authors recorded temperatures ranging from $27-32^{\circ} \mathrm{C}$, which were also similar to our experiment $\left(25-31^{\circ} \mathrm{C}\right)$ and detected low concentrations of DO (1.30-2.02 $\left.\mathrm{mg} \mathrm{L}^{-1}\right)$. In contrast, in our assessment of biofloc induced with microalgae and probiotics, DO concentration did not show values lower than $5.0 \mathrm{mg} \mathrm{L}^{-1}$. The Brock \& Main (1994) recommended conditions (4-10 $\mathrm{mg} \mathrm{L}^{-1}$ ) to ensure good shrimp growth in BFT systems were maintained in our study. It is worth noting two important aspects regarding temperature: 1) considering the relationship between temperature increments and DO declines detected by Ponce-Palafox et al. (2019), these results are encouraging, because despite our assessment was performed in a coastal area where temperature increases considerably, low concentrations of DO were not detected, 2) in this study, the microalgal densities in bioflocs evidenced that the diatoms' concentration remained stable, without dissipating or blooming. High temperatures can benefit the growth of cyanobacteria (Lan et al. 2015), and the productivity of microalgal biomass and high temperature combined with a high 

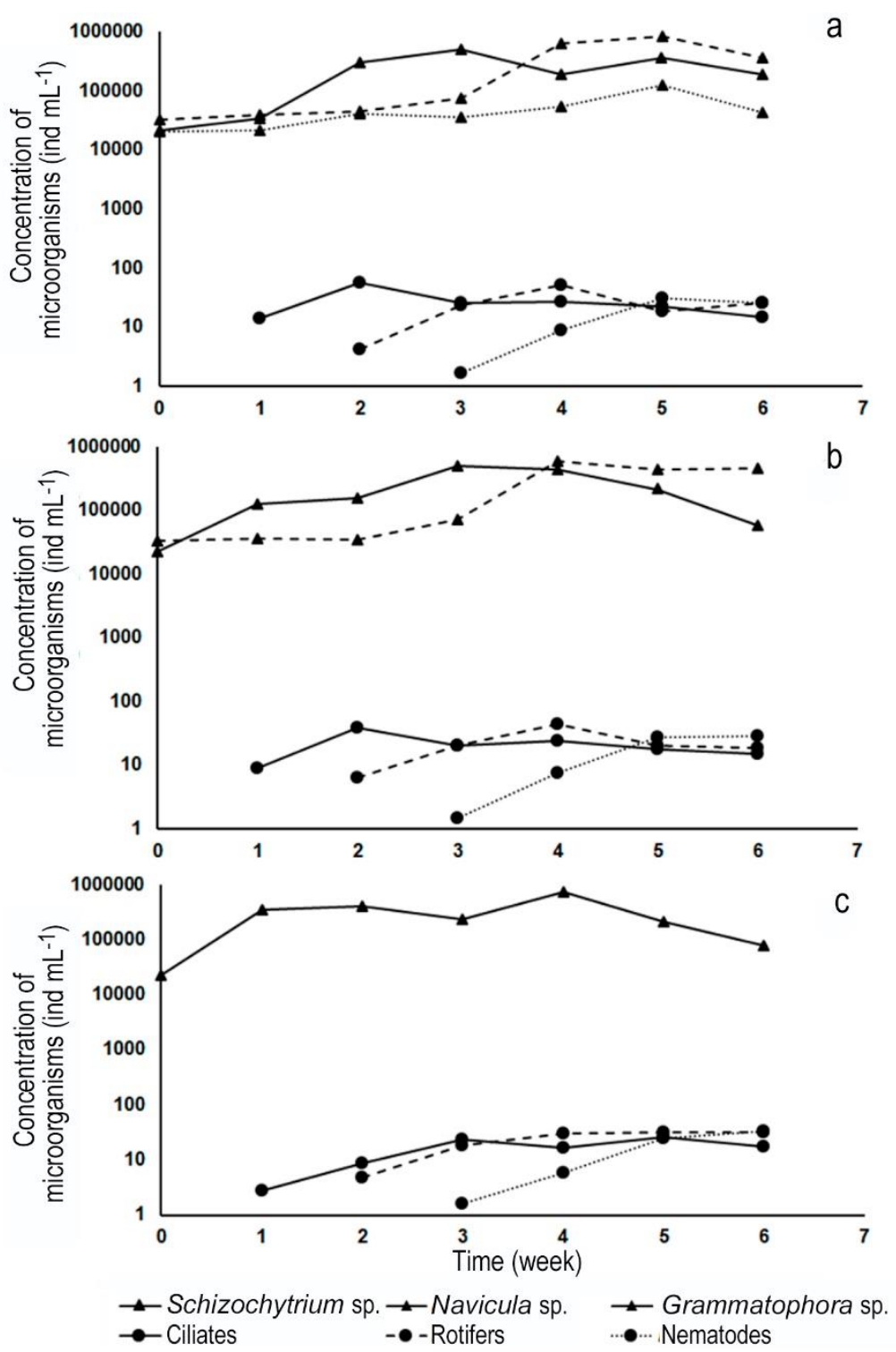

Figure 3. Concentrations of microorganisms per $\mathrm{mL}^{-1}$ of inoculated microalgae, ciliates, rotifers, and nematodes in bioflocs . a) BFD1 induced with Schizochytrium sp., Grammatophora sp. and Navicula sp., b) BFD2 induced with Schizochytrium sp. and Navicula sp., c) BFS induced with Schizochytrium sp. in Penaeus vannamei culture during six weeks.

luminosity can affect diatom growth. Hence, low luminosity is more suitable for these microorganisms' growth (Lan et al. 2015). In this study, the microalgal densities of bioflocs are typical of cultures obtained at mean temperatures of $27^{\circ} \mathrm{C}$ and without high luminosity. Besides, the molasses supplied contributed to maintaining the heterotrophic microbiota and the induced diatoms during the culture period, which are needed to obtain good quality flocs that feed other microorganisms (Milhazes-Cunha \& Otero 2017). Typically in heterotrophic systems, decreases in alkalinity and $\mathrm{pH}$ during rearing in BFT systems; in this work, the mean concentration of alkalinity was within the acceptable range: $>100 \mathrm{mg} \mathrm{L}^{-1}$ and $\mathrm{pH}$ levels above 7 for P. vannamei (Furtado et al. 2011). During this study, were necessary additions of sodium bicarbonate in the three treatments, thus favoring physical and chemical water quality conditions for biofloc development and the growth of $P$. vannamei.

Another important parameter for $P$. vannamei culture is nitrogen-containing compounds' concentration (Valencia-Castañeda et al. 2019). In this study, the concentrations of ammonium, nitrites, and nitrates in all bioflocs were within the range recommended for shrimp culture (Van Wyk 1999, Valencia-Castañeda et al. 2019). Ammonium did not show significant differences among treatments during the experimental period. However, the variations observed were similar to the data reported by Reis et al. (2019), where ammo- 
Table 2. Proximal composition (percentage of dry weight) of biofloc induced with Schizochytrium sp., Grammatophora sp. and Navicula sp. (BFD1), biofloc induced with Schizochytrium sp. and Navicula sp. (BFD2), and biofloc induced with Schizochytrium sp. (BFS) during six weeks of culture. Mean values \pm standard deviation, $(\mathrm{n}=3)$ of a set of four simples per treatment. Different superscript letters indicates significant differences among treatment groups $(P<0.05)$.

\begin{tabular}{lccc}
\hline \multirow{2}{*}{ Constituent (\%) } & \multicolumn{3}{c}{ Treatment } \\
\cline { 2 - 4 } & BFTD1 & BFD2 & BFS \\
\hline Proteins & $28.12 \pm 0.50^{\mathrm{a}}$ & $26.39 \pm 1.04^{\mathrm{a}}$ & $23.81 \pm 0.99^{\mathrm{b}}$ \\
Lipids & $22.44 \pm 0.80^{\mathrm{a}}$ & $17.31 \pm 0.55^{\mathrm{b}}$ & $14.31 \pm 0.41^{\mathrm{c}}$ \\
Carbohydrates & $30.11 \pm 0.23^{\mathrm{c}}$ & $35.42 \pm 0.91^{\mathrm{b}}$ & $43.24 \pm 1.83^{\mathrm{a}}$ \\
Ashes & $19.17 \pm 0.23^{\mathrm{a}}$ & $19.50 \pm 0.09^{\mathrm{a}}$ & $18.72 \pm 0.51^{\mathrm{a}}$ \\
\hline
\end{tabular}

Table 3. Mean values of growth performance parameters of juveniles of Penaeus vannamei cultured during six weeks in biofloc induced with Schizochytrium sp., Grammatophora sp. and Navicula sp. (BFD1), biofloc induced with Schizochytrium sp. and Navicula sp. (BFD2), and biofloc induced with Schizochytrium sp. (BFS). Mean values \pm standard deviation. Different superscript letters indicates significant differences among treatment groups; one-way ANOVA $(P<$ $0.05)$.

\begin{tabular}{lccc}
\hline \multirow{2}{*}{ Parameter } & \multicolumn{3}{c}{ Treatment } \\
\cline { 2 - 4 } & BFD1 & BFD2 & BFS \\
\hline Initial weight $(\mathrm{g})$ & $1.40 \pm 0.22$ & $1.40 \pm 0.22$ & $1.40 \pm 0.22$ \\
Final weight $(\mathrm{g})$ & $8.00 \pm 0.22$ & $8.10 \pm 0.21$ & $7.80 \pm 0.50$ \\
Specific growth rate $\left(\% \mathrm{~d}^{-1}\right)$ & $3.12 \pm 0.05$ & $3.14 \pm 0.05$ & $3.06 \pm 0.12$ \\
Feed conversion ratio $(\%)$ & $0.89 \pm 0.02^{\mathrm{b}}$ & $0.97 \pm 0.02^{\mathrm{a}}$ & $0.97 \pm 0.06^{\mathrm{a}}$ \\
Survival rate $(\%)$ & $80.08 \pm 0.01^{\mathrm{a}}$ & $72.49 \pm 3.64^{\mathrm{b}}$ & $71.71 \pm 001^{\mathrm{b}}$ \\
Weekly growth rate & $1.11 \pm 0.04$ & $1.12 \pm 0.04$ & $1.06 \pm 0.08$ \\
\hline
\end{tabular}

nium increased during the first week and decreased towards the end of the experimental period. The mean values of ammonium in the three treatments were maintained effectively below toxic levels (De Lourdes et al. 2014), oxidation was performed by bacteria, and removal by microalgae.

During week one, the ammonium concentration and volume of biofloc increased at all treatments; this could be related to the process of nitrogen-compound accumulation that derives from the increasing heterotrophic bacteria at the beginning of the culture, which improved the water quality (Emerenciano et al. 2007). The formation of flocs was also observed during week one, which is consistent with Fatimah et al. (2019) and Feng et al. (2019), who noted that the initial formation of microbial aggregates modifies the physical characteristics to develop biogeochemical processes associated with biofloc, eliminating the total ammoniacal nitrogen (Ebeling et al. 2006). These results suggest that in the three induced biofloc treatments, the formation of microbial aggregates in week two was comprised of nitrification microorganisms associated with the oxidation of ammonia to nitrites, which is concordant with the reported by Ebeling et al. (2006), Van Rijn et al. (2006) and Crab (2010). In addition, nitrite-oxidizing bacteria are present at certain stages of the culture systems; in this study, heterotrophic bacteria presence was evident when the nitrate concentration increased, reaching values higher than $10 \mathrm{mg} \mathrm{L}^{-1}$ after week four, which is consistent with Reis et al. (2019). Results did not show significant differences among the three microalgal treatments regarding the concentration of nitrogen compounds. However, the treatments supplied with diatoms maintained lower values, which suggests their species of microalgae that were tested do not show differences in the nutrients removal in water. However, we do not know if these trends are maintained over a more prolonged time culture.

Some works (Lomas \& Glibert 2000, Yang et al. 2014) highlight diatoms for their ability to remove nitrates, also remove phosphorus at temperatures ranging $15-25^{\circ} \mathrm{C}$ (Ji et al. 2019); however, this was not observed in this work. During culture, at $15-25^{\circ} \mathrm{C}$, microalgae and bacteria interact in processes that improve the water quality (Delgadillo-Mirquez et al. 2016), explaining our results. In this experiment, the temperature was maintained around $27^{\circ} \mathrm{C}$, which, according to the reports mentioned earlier, enhances microalgal growth and the microalga-bacteria interactions to perform nitrification processes. Thus, main- 
taining suitable temperature conditions for diatoms in culture fosters the elimination of toxic compounds for shrimp. Results also suggest that diatoms enhance the formation of biofloc by segregating the mucilaginous substances described by Sanka et al. (2017) and Daglio et al. (2018), these substances adhere bacteria to join biofloc and also act as feed for these microorganisms, as noted by Fimbres-Olivarria et al. (2018) in their study with Navicula. Also, diatoms have the advantage of presenting different sizes within bioflocs and provide the nutrients needed to grow different microorganisms such as ciliates and rotifers. In turn, ciliates and rotifers improved the quality of biofloc, and for this study, they were determined their concentration in the induced bioflocs and the concentration of bacteria that could affect shrimp culture throughout the experimental period. It is important to monitor pathogenic bacteria in shrimp culture, especially those of the genus Vibrio, which affects the Pacific white shrimp culture (Muthukrishnan et al. 2019). Pacheco-Vega et al. (2018) used Lactobacillus plantarum and Schizochytrium sp. in shrimp culture and evidenced that this association inhibits concentrations of Vibrio spp. more efficiently than commercial probiotics. In this sense, the implementation of L. plantarum TD19 with microalgae can help shrimp to maintain a balanced intestinal microbiota and to resist Vibrio spp., which could be similar to the use of bacteria of the genus Bacillus as probiotics (Zheng \& Wang et al. 2017, Amoah et al. 2019, Kuebutornye et al. 2019).

Results indicated that the probiotic bacteria $L$. fermentum TD19 combined with Schizochytrium sp. and diatoms favored culture, LAB increased in biofloc and the digestive tract of shrimp concentrations of Vibrio spp. decreased in culture and shrimp. Kongnum \& Hongpattarakere (2012) found that shrimp fed supplemented diet with probiotics presented higher concentrations of LAB and decreased concentrations of Vibrio spp. in shrimp by adding L. plantarum. In this study, the same tendency was observed with the addition of $L$. fermentum TD19 and microalgae, the LAB concentration was higher than $1.00 \times 10^{3} \mathrm{CFU} \mathrm{g}^{-1}$, and low concentrations of Vibrio spp. were detected by the end of the experimental period.

The lowest concentration of Vibrio spp. was detected in the biofloc of BFD1, which presented the highest concentration of ciliates and the best shrimp survival. Ciliates are important bioindicators of water quality (Luna-Pabello et al. 1990) because these microorganisms filter water to feed on bacteria, benefiting BFT by reducing the bacterial load. Ciliates are employed in wastewater treatment plants (Esteban et al. 1991) to reduce the number of bacteria in activated sludge and improve flocculation (Pajdak-Stós et al. 2017). This kind of process could favor the bioflocs, given that the number of ciliates and the volume of biofloc presented a directly proportional relationship.

Also, nematodes were another relevant group within biofloc. These microorganisms contribute to biofilm formation in flocs and the removal of organic matter and wastes (Du Preez et al. 2018). Moreover, nematodes have been suggested as live feed in shrimp culture (Santiago et al. 2003, Schlechtriem et al. 2004). In this study, densities of nematodes and rotifers were similar among the three treatments, although significant differences were detected regarding proximal composition. Biofloc of treatments supplied with diatoms presented higher percentages of protein and lipids, which indicates that microalgae influence the nutritional value of biofloc regardless of the similarities in rotifer and nematode densities among treatments. Pacheco-Vega et al. (2015) evaluated the brine shrimp Artemia franciscana as an individual diet and combined with Navicula sp. and Schizochytrium sp., the highest dry weight of the brine shrimp was obtained in the combined diet; a similar tendency was found in this biofloc combined with microalgae.

Microalgae enhance biofloc production by forming nutritive floccules; these microorganisms act as feed for heterotrophic bacteria by extracellular exchange; besides, microalgae remove nitrates and segregate mucilaginous substances, increase the diversity of microorganisms comprising the biofloc, and improved the proximal composition of flocs (Fuentes et al. 2016). Fleckenstein et al. (2019) used probiotic bacteria without microalgae to induce flocculation. They reported protein and lipid values lower than 6 and 1\%, respectively, which contrasts with our results, suggesting that microalgae should be additionally supplied to biofloc to increase their nutritional value. Concordantly, Reis et al. (2019) stated that biofloc must contain photoautotrophic microorganisms such as microalgae to improve the quality of proteins and lipids and suggested that the systems should be exposed to 12:12 $\mathrm{h}$ natural light-dark regimes to improve nitrification.

The microalgae considered in this experiment have been scarcely investigated in biofloc. Pacheco-Vega et al. (2018) included Schizochytrium sp. in BFT and reported that proteins ranged $12-16 \%$ and lipids 18 $28 \%$. We obtained similar results, although the quality of proteins and lipids might have also been enhanced by the biodiversity of microorganisms (bacteria, ciliates, rotifers, and nematodes) comprising the biofloc. In BFT, microbiota changes derive from biofloc composition variations, temperature, salinity, light intensity, photoperiod, nutrient availability, population density, 
and water quality, among other culture conditions (Martínez-Córdova et al. 2015, Pacheco-Vega et al. 2018). In this study, microorganism densities in the biofloc served as indicators of diatoms' presence in the system and survival and feed conversion ratio (FCR) in treatment BFD1, unlike in treatment BFS, which was not supplied with diatoms. Many ciliates, rotifers, and nematodes in biofloc indicated a high availability of nutrients that act as dietary supplements (Avnimelech 2009), which fostered the survival and FCR values in treatment BFD1.

In treatment BFD1, the survival of $80 \%$ and FCR lower than 1.00 are good values for hyper-intensive shrimp culture. Regarding FCR, the values reported by Kumar et al. (2018) (FCR close to 1.00) and PachecoVega et al. $(2018)(\mathrm{FCR}=1.18)$ for shrimp cultures without diatoms were qualified as suitable zootechnical values similar results in the three treatments, evidencing a reasonable consumption of commercial feed and growth performance and survival of $P$. vannamei. Our shrimp densities (350 ind $\mathrm{m}^{-3}$ ) were favorable in terms of growth, given that Krummenauer et al. (2011) reported densities $=300$ and 400 ind $\mathrm{m}^{-3}$; $\mathrm{FCR}=1.29$ and 2.41 , and survival $=81.2$ and 75.0, respectively, which are similar to our results. Therefore, implementing microalgae of high nutritional quality is advantageous for zootechnical parameters during shrimp culture using BFT, as evidenced in treatment BFD1.

The induction of flocs with the three microalgae employed in this experiment is favorable for hyperintensive shrimp culture, especially in aquaculture farms that need a constant availability ( $24 \mathrm{~h})$ of highquality nutritional supplies. Also, biofloc induced with microalgae can be easily scaled at the desired volumes, which benefits costs, as reflected in this study's FCR value. Becerril-Cortes et al. (2018) used diatoms as natural feed for shrimp and obtained good zootechnical results in growth, weight, and FCR. The microalgae considered in this study present high nutritional quality; this statement was also evidenced in the proximate analyses performed by Pacheco-Vega et al. (2015) as follows: Schizochytrium sp. with $19.5 \%$ of carbohydrates, $25 \%$ of lipids, and $26.3 \%$ of protein; Navicula sp. with $7.7 \%$ of carbohydrates, $31.7 \%$ of lipids, and $12 \%$ of protein; and Grammatophora sp. with $9.3 \%$ of carbohydrates, $32.3 \%$ of lipids, and $22.7 \%$ of protein. Possibly these nutritional characteristics contributed to the better survival of shrimp in BFD1 compared to treatment BDS. Hence, we suggest that diatoms (e.g. Navicula spp.) and other microalgae should be employed as biofloc inducers in shrimp culture in order to obtain the best production values and to profit from the nutritional properties of these microorganisms
(Wells et al. 2017), as well as to enhance the formation of biofloc due to the segregation of substances that act as antioxidants and antimicrobials. Ferreira et al. (2014) used Navicula sp. to feed $P$. vannamei postlarvae and obtained fair values of final weight, weight gain, biomass gain, conversion index, specific growth rate survival. Concordantly, using Navicula sp. and Grammatophora sp. were also favorable for shrimp growth to induce biofloc, as evidenced in treatment BFD1. Schizochytrium aggregatum has a substantial oxidative capacity that improves feeding for shrimp ( $\mathrm{Lv}$ et al. 2015). Thus, the additional inclusion of Navicula sp. and Grammatophora sp. in cultures can reduce the quantity of commercial feed since biofloc constitutes a nutritional supply consumed by shrimp.

\section{CONCLUSIONS}

In this study, we concluded that the addition of Grammatophora sp., Navicula sp. and Schizochytrium sp. and the probiotic bacteria Lactobacillus plantarum TD19 in shrimp culture improved the formation of biofloc and the development of microorganisms such as ciliates, rotifers, and nematodes, which are live feed for shrimp. With the addition of these microalgae and probiotic bacterium into the culture system, dissolved oxygen was maintained at a suitable level for the formation of biofloc. Moreover, bacteria that grow during culture contributes to transforming ammonium to nitrates, avoiding toxic levels for shrimp. Also, diatoms into biofloc transform ammonia, nitrite, and nitrate to biomass, increasing the quantity of protein and lipids in flocs and reduces the concentration of Vibrio spp. in water and the digestive tract of shrimp, improving survival and FCR. Thus, to maintain a low FCR in a culture of Penaeus vannamei in a biofloc technology system (BFT), we suggest that biofloc should be induced with the microalgae Grammatophora sp., Navicula sp. and Schizochytrium sp. and the probiotic bacteria L. plantarum TD19. Greater efficiency of the BFT culture system can be obtained by adding these microorganisms into the system.

\section{ACKNOWLEDGEMENTS}

I (J.M.P.V.) would like to offer this work in memoriam of Dr. Marco A. Cadena-Roa (1953-2020) for his encouragement at the beginning of my work in the field of aquaculture. Authors thank Consejo Nacional de Ciencia y Tecnología (CONACyT) for the graduate scholarship provided, and Laboratorio de Ciencia y Tecnología de Alimentos. Authors are also grateful for the technical support provided by Elizabeth Pérez 
Bravo, Oscar M. Valdez-Cano, Anais Lucero Olachea, Elena Contreras Sillero, Patricia Hinojosa Baltazar and Gabriela Mendoza Carrion.

\section{REFERENCES}

Aladro-Lubel, M. 2009. Manual de protozoarios. Universidad Autónoma de México, Ciudad de México.

Amoah, K., Huang, Q.C., Tan, B.P., Zhang, S., Chi, S.Y., Yang, Q.H. \& Dong, X.H. 2019. Dietary supplementation of probiotic Bacillus coagulans ATCC 7050 improves the growth performance, intestinal morphology, microflora, immune response, and disease confrontation of Pacific white shrimp, Litopenaeus vannamei. Fish and Shellfish Immunology, 87: 796808.

American Public Health Association (APHA). 1995. WPCF, standard methods for the examination of water and wastewater. APHA/AWWA/WEF, Washington D.C.

Arias-Moscoso, J.L., Espinoza-Barrón, L.G., MirandaBaeza, A., Rivas-Vega, M.E. \& Nieves-Soto, M. 2018. Effect of commercial probiotics addition in a biofloc shrimp farm during the nursery phase in zero water exchange. Aquaculture Reports, 11: 47-52.

Avnimelech, Y. 1999. Carbon/nitrogen ratio as a control element in aquaculture systems. Aquaculture, 176: 227-235.

Avnimelech, Y. 2009. Biofloc technology. A practical guide book. World Aquaculture Society, Baton Rouge.

Avnimelech, Y. 2012. Biofloc technology. A practical guide book. The World Aquaculture Society, Baton Rouge.

Balcázar, J.L., Rojas, L.T. \& Cunningham, D.P. 2017. Effect of the addition of four potential probiotic strains on the survival of pacific white shrimp (Litopenaeus vannamei) following immersion challenge with Vibrio parahaemolyticus. Journal of invertebrates Pathology, 96: 147-150.

Becerril-Cortés, D., Monroy-Dosta, M.C., Coelho, M., Castro-Mejía, G., Schettino, B. \& Vela-Correa, G. 2018. Effect on nutritional composition of produced bioflocs with different carbon sources (molasses, coffee waste and rice bran) in biofloc system. International Journal of Fisheries and Aquatic Studies, 6: 541-547.

Bligh, E.G. \& Dyer, W.J. 1959. A rapid method of total lipid extraction and purification. Canadian Journal Biochemistry and Physiology, 37: 911-917.

Brock, J. \& Main, K.L. 1994. A guide to the common problems and diseases of cultured Penaeus vannamei. World Aquaculture Society, Baton Rouge.

Correia, E.S., Wilkenfeld, J.S., Morris, T.C., Wei, L., Prangnell, D.I. \& Samocha, T.M. 2014. Intensive nursery production of the Pacific white shrimp Litopenaeus vannamei using two commercial feeds with high and low protein content in a bioflocdominated system. Aquacultural Engineering, 59: 4854.

Crab, R. 2010. Bioflocs technology: an integrated system for the removal of nutrients and simultaneous production of feed in aquaculture. Ph.D. Thesis, Ghent University, Ghent.

Crab, R., Defoirdt, T., Bossier, P. \& Verstraete, W. 2012. Biofloc technology in aquaculture: beneficial effects and future challenges. Aquaculture, 356-357: 351-356.

Daglio, Y., Sacristán, H., Ansaldo, M. \& Rodríguez, M.C. 2018. Benthic diatoms from Potter Cove, 25 de Mayo (King George) Island, Antarctica: mucilage and glucan storage as a C-source for limpets. Polar Science, 15: 39-48.

De Lourdes, M., Sonnenholzner, S., Wille, M. \& Sorgeloos, P. 2014. Ammonia tolerance of Litopenaeus vannamei (Boone) larvae. Aquaculture Research, 45: 470-475.

Delgadillo-Mirquez, L., Lopes, F., Taidi, B. \& Pareau, D. 2016. Nitrogen and phosphate removal from wastewater with a mixed microalgae and bacteria culture. Biotechnology Reports, 11: 18-26.

Du Preez, G.C., Daneel, M.S., Wepener, V. \& Fourie, H. 2018. Beneficial nematodes as bioindicators of ecosystem health in irrigated soils. Applied Soil Ecology, 132: $155-168$.

Dubois, M., Gilles, K.A., Hamilton, J.K., Rebers, P.A. \& Smith, F. 1956. Colorimetric method for determination of sugars and related substances. Analytical Chemistry, 28: 350-356.

Ebeling, J.M., Timmons, M.B. \& Bisogni, J.J. 2006. Engineering analysis of the stoichiometry of photoautotrophic, autotrophic, and heterotrophic removal of ammonia-nitrogen in aquaculture systems. Aquaculture, 257: 346-358.

Emerenciano, M.G.C., Wasielesky, W., Soa, R.B., Ballester, E.C., Izeppi, E.M. \& Cavalli, R.O. 2007. Crescimento e sobrevivência do camarão-rosa (Farfantepenaeus paulensis) na fase de berçário em meio heterotrófico. Acta Scientiarum - Biological Sciences, 29: 1-7.

Esteban, G., Téllez, C. \& Bautista. L.M. 1991. Dynamics of ciliated protozoa communities in the activatedsludge process. Water Research, 25: 967-972.

Fatimah, N., Pande, G.S.J., Natrah, F., Meritha, W.W., Widanarni, S.A. \& Ekasari, J. 2019. The role of microbial quorum sensing on the characteristics and functionality of bioflocs in aquaculture systems. Aquaculture, 504: 420-426.

Feng, Z., Sun, Y., Li, T., Meng, F. \& Wu, G. 2019. Operational pattern affects nitritation, microbial 
community, and quorum sensing in nitrifying wastewater treatment systems. Science of the Total Environment, 677: 456-465.

Ferreira, M.Y., Brito, L.O., Figueiredo da Silva, C.V., Sobral dos Santos, I.G. \& Olivera-Galvez, A. 2014. Effect of addition of Navicula sp. on plankton composition and postlarvae growth of Litopenaeus vannamei reared in culture tanks with zero water exchange. Latin American Journal of Aquatic Research, 42: 427-437.

Fimbres-Olivarria, D., Carvajal-Millan, E., Lopez-Elias, J.A., Martinez-Robinson, K.G., Miranda-Baeza, A., Martinez-Cordova, L.R. \& Valdez-Holguin, J.E. 2018. Chemical characterization and antioxidant activity of sulfated polysaccharides from Navicula sp. Food Hydrocolloids, 75: 229-236.

Fleckenstein, L.J., Tierney, T.W., Fisk, J.C. \& Ray, A.J. 2019. Effects of supplemental LED lighting on water quality and Pacific white shrimp (Litopenaeus vannamei) performance in intensive recirculating systems. Aquaculture, 504: 219-226.

Fuentes, J., Garbayo, I., Cuaresma, M., Montero, Z., González-del-Valle, M. \& Vilchez, C. 2016. Impact of microalgae-bacteria interactions on the production of algal biomass and associated compounds. Marine Drugs, 14: 100.

Furtado, P.S., Poersch, L.H. \& Wasielesky Jr., W. 2011. Effect of calcium hydroxide, carbonate and sodium bicarbonate on water quality and zootechnical performance of shrimp Litopenaeus vannamei reared in bio-flocs technology (BFT) systems. Aquaculture, 321:130-135.

Guillard, R.R. 1975. Culture of phytoplankton for feeding marine invertebrates. Culture of Marine Invertebrate Animals, 3: 29-60.

Hargreaves, J. 2013. Biofloc production systems for aquaculture. Southern Regional Aquaculture Center, Publication 4503, Stoneville.

Hari, B., Kurup, B.M., Varghese, J.T., Schrama, J.W. \& Verdegem, M.C.J. 2004. Effects of carbohydrate addition on production in extensive shrimp culture systems. Aquaculture, 241: 179-194.

Hernández-Castro, J.E. \& Pacheco-Vega, J.M. 2015. Interacción mixotrófica de microalgas marinas y bacterias probióticas. Editorial Académica Española, Madrid.

Ji, L., Song, W., Wei, D., Jiang, D., Cai, L., Wang, Y. \& Zhang, H. 2019. Modified mussel shell powder for microalgae immobilization to remove $\mathrm{N}$ and $\mathrm{P}$ from eutrophic wastewater. Bioresource Technology, 284: 36-42.

Kongnum, K. \& Hongpattarakere, T. 2012. Effect of Lactobacillus plantarum isolated from digestive tract of wild shrimp on growth and survival of white shrimp (Litopenaeus vannamei) challenged with Vibrio harveyi. Fish and Shellfish Immunology, 32: 170-177.

Krummenauer, D., Peixoto, S., Cavalli, R.O., Poersch, L.H. \& Wasielesky, W. 2011. Superintensive culture of white shrimp, Litopenaeus vannamei, in a biofloc technology system in southern Brazil at different stocking densities. Journal of the World Aquaculture Society, 42: 726-733.

Kuebutornye, F.K.A., Abarike, E.D. \& Lu, Y. 2019. A review on the application of Bacillus as probiotics in aquaculture. Fish and Shellfish Immunology, 87: 820828.

Kumar, S.V., Pandey, P.K., Anand, T., Bhuvaneswari, G.R., Dhinakaran, A. \& Kumar, S. 2018. Biofloc improves water, effluent quality and growth parameters of Penaeus vannamei in an intensive culture system. Journal of Environmental Management, 215: 206-215.

Lan, S., Wu, L., Zhang, D. \& Hu, C. 2015. Effects of light and temperature on open cultivation of desert cyanobacterium Microcoleus vaginatus. Bioresource Technology, 182: 144-150.

Lin, H.Z., Guo, Z., Yang, Y., Zheng, W. \& Li, Z.J. 2004. Effect of dietary probiotics on apparent digestibility coefficients of nutrients of white shrimp Litopenaeus vannamei Boone. Aquaculture Research, 35: 14411447.

Lomas, M.W. \& Glibert, P.M. 2000. Comparisons of nitrate uptake, storage, and reduction in marine diatoms and flagellates. Journal of Phycology, 36: 903-913.

Lowry, O.H., Rosebrough, N.J., Farr, A.L. \& Randall, R.J. 1951. Protein measurement with the Folin phenol reagent. Journal of Biological Chemistry, 193: 265275.

Luna-Pabello, V.M., Mayén, R., Olvera-Viascan, V., Saavedra, J. \& Durán de Bazúa, C. 1990. Ciliated protozoa as indicators of a wastewater treatment system performance. Biological Wastes, 32: 81-90.

Lv, J., Jingfang, D., Yu, B.Z., Fengling, B., Honngfei, Z. \& Jianrong, L. 2017. Purification and antibacterial mechanism of fish-borne bacteriocin and its application in shrimp (Penaeus vannamei) for inhibiting Vibrio parahaemolytycus. World Journal of Microbiology and Biotechnology, 33: 156.

Lv, J., Yang, X., Ma, H., Hu, X., Wei, Y., Zhou, W. \& Li, L. 2015. The oxidative stability of microalgae oil (Schizochytrium aggregatum) and its antioxidant activity after simulated gastrointestinal digestion: relationship with constituents. European Journal of Lipid Science and Technology, 117: 1928-1939. 
Ma, C.W., Cho, Y.S. \& Oh, K.H. 2009. Removal of pathogenic bacteria and nitrogen by Lactobacillus spp. JK-8 and JK-11. Aquaculture, 287: 266-270.

Martínez-Córdova, L.R., Emerenciano, M., MirandaBaeza, A. \& Martínez-Porchas, M. 2015. Microbialbased systems for aquaculture of fish and shrimp: an updated review. Reviews in Aquaculture, 7: 131-148.

Malara, G. \& Charra, R. 1972. Dosages des proteines partiulaires selon la méthode de Lowry. Université de Paris, Station Zoologique, Villefrenche-Sur-Mer, Notes de Travail, 6: 11.

Milhazes-Cunha, H. \& Otero, A. 2017. Valorization of aquaculture effluents with microalgae: the integrated multi-trophic aquaculture concept. Algal Research, 24: 416-424.

Muthukrishnan, S., Defoirdt, T., Ina-Salwany, M.Y., Yusoff, F.M., Shariff, M., Ismail, S.I. \& Natrah, I. 2019. Vibrio parahaemolyticus and Vibrio harveyi causing acute hepatopancreatic necrosis disease (AHPND) in Penaeus vannamei (Boone, 1931) isolated from Malaysian shrimp ponds. Aquaculture, 511: 734227.

Pacheco-Vega, J.M., Cadena-Roa, M.A., Ascencio, F., Rangel-Dávalos, C. \& Rojas-Contreras, M. 2015. Assessment of endemic microalgae as potential food for Artemia franciscana culture. Latin American Journal of Aquatic Research, 43: 23-32.

Pacheco-Vega, J.M., Cadena-Roa, M.A., Leyva-Flores, J.A., Zavala-Leal, O.I., Pérez-Bravo, E. \& RuizVelazco, J.M.J. 2018. Effect of isolated bacteria and microalgae on the biofloc characteristics in the Pacific white shrimp culture. Aquaculture Reports, 11: 24-30.

Pajdak-Stós, A., Sobczyk, M., Fiałkowska, E., KocerbaSoroka, W. \& Fyda, J. 2017. The effect of three different predatory ciliate species on activated sludge microfauna. European Journal of Protistology, 58: 8793.

Ponce-Palafox, J.T., Pavia, Á.A., Mendoza-López, D.G., Arredondo-Figueroa, J.L., Lango-Reynoso, F., Castañeda-Chávez, M. \& Peraza-Gómez, V. 2019. Response surface analysis of temperature-salinity interaction effects on water quality, growth and survival of shrimp Penaeus vannamei postlarvae raised in biofloc intensive nursery production. Aquaculture, 503: 312-321.

Quijano, G., Arcila, J.S. \& Buitrón, G. 2017. Microalgalbacterial aggregates: applications and perspectives for wastewater treatment. Biotechnology Advances 35: 772-781.

Reis, W.G., Wasielesky, W., Abreu, P.C., Brandão, H. \& Krummenauer, D. 2019. Rearing of the Pacific white shrimp Litopenaeus vannamei (Boone, 1931) in BFT system with different photoperiods: effects on the microbial community, water quality and zootechnical performance. Aquaculture, 508: 19-29.
Roy, S.S. \& Pal, R. 2015. Microalgae in aquaculture: a review with special references to nutritional value and fish dietetics. Proceedings of the Zoological Society, 68: $1-8$

Sanka, I., Suyono, E.A. \& Alam, P. 2017. The effects of diatom pore-size on the structures and extensibilities of single mucilage molecules. Carbohydrate Research, 448: 35-42.

Santiago, C.B., Gonzal, A.C., Ricci, M. \& Harpaz, S. 2003. Response of bighead carp Artistichthys nobilis and Asian catfish Clarias macrocephalus larvae to free-living nematode Panagrellus redivivus as alternative feed. Journal of Applied Ichthyology, 19: 239-243.

Schlechtriem, C., Ricci, M., Focken, U. \& Becker, K. 2004. Mass produced nematodes Panagrellus redivivus as live food for rearing carp larvae: preliminary results. Aquaculture Research, 35: 547551.

Schveitzer, R., Arantes, R., Costodio, P.F.S., Do Espirito Santo, C.M., Arana, L.V., Seiffert, W.Q. \& Andreatta, E.R. 2013. Effect of different biofloc levels on microbial activity, water quality and performance of Litopenaeus vannamei in a tank system operated with no water exchange. Aquacultural Engineering, 56: 5970.

Serra, F.P., Gaona, A.C.P., Furtado, P.S., Poersch, L.H. \& Wasielesky, J.W. 2015. Use of different carbon sources for the biofloc system adopted during the nursery and grow-out culture of Litopenaeus vannamei. Aquaculture International, 23: 1325-1339.

Sun, L., Ren, L., Zhuang, X., Ji, X., Yan, J. \& Huang, H. 2014. Differential effects of nutrient limitations on biochemical constituents and docosahexaenoic acid production of Schizochytrium sp. Bioresource Technology, 159: 199-206.

Timmons, M.B., Ebeling, J.M., Wheaton, F.W., Sommerfelt, S.T. \& Vinci, B.J. 2002. Microbial biofloc and protein levels in green tiger shrimp. Recirculating aquaculture systems. Caruga Aqua Ventures, New York.

Valencia-Castañeda, G., Frías-Espericueta, M.G., VanegasPérez, R.C., Chávez-Sánchez, M.C. \& Páez-Osuna, F. 2019. Toxicity of ammonia, nitrite and nitrate to Litopenaeus vannamei juveniles in low-salinity water in single and ternary exposure experiments and their environmental implications. Environmental Toxicology and Pharmacology, 70: 103193.

Van Rijn, J., Tal, Y. \& Schreier, H.J. 2006. Denitrification in recirculating systems: theory and applications. Aquacultural Engineering, 34: 364-376.

Van Wyk, P. 1999. Nutrition and feeding of Litopenaeus vannamei in intensive culture systems. In: Van Wyk, 
P., Davis-Hodgkins, M., Laramore, R., Main, K.L., Mountain, J. \& Scarpa, J. (Eds.). Farming marine shrimp in recirculating freshwater systems. Florida Department of Agriculture and Consumer Services Harbor Branch Oceanic Institute, Florida, 7: 125-140.

Wei, Y.F., Liao, S.A. \& Wang, A. 2016. The effect of different carbon sources on the nutritional composition, microbial community and structure of bioflocs. Aquaculture, 465: 88-93.

Wells, M.L., Potin, P., Craigie, J.S., Raven, J.A., Merchant, S.S., Helliwell, K.E. \& Brawley, S.H. 2017. Algae as nutritional and functional food sources: revisiting our understanding. Journal of Applied Phycology, 29: 949-982.

White, J.N.C. 1987. Biochemical composition and energy content of six species of phytoplankton used in mariculture of bivalves. Aquaculture, 60: 231-241.

Xie, J.J., Liu, Q., Liao, S., Fang, H.H., Yin, P., Xie, S.W. \& Niu, J. 2019. Effects of dietary mixed probiotics on growth, non-specific immunity, intestinal morphology and microbiota of juvenile Pacific white shrimp, Litopenaeus vannamei. Fish and Shellfish Immunology, 90: 456-465.

Received: 12 April 2020; Accepted: 3 November 2020
Xu, W.J. \& Pan, L.Q. 2013. Dietary protein level and C/N ratio manipulation in zero-exchange culture of Litopenaeus vannamei: evaluation of inorganic nitrogen control, biofloc composition and shrimp performance. Aquaculture Research, 45: 1842-1851.

Yang, M., Zhao, W. \& Xie, X. 2014. Effects of nitrogen, phosphorus, iron and silicon on growth of five species of marine benthic diatoms. Acta Ecologica Sinica, 34: 311-319.

Zar, J. 1996. Biostatistical analysis. Prentice-Hall, New Jersey.

Zheng, C.N. \& Wang, W. 2017. Effects of Lactobacillus pentosus on the growth performance, digestive enzyme and disease resistance of white shrimp, Litopenaeus vannamei (Boone, 1931). Aquaculture Research, 48: 2767-2777. 